\title{
Approach to Fever in Sub-Saharan Tropical Africa
}

\section{Sahra Altı Tropikal Afrika' da Ateşe Yaklaşım}

Alparslan Merdin ${ }^{1}$ Özer Birge ${ }^{2}$, Fatma Avcı Merdin ${ }^{3}$

'Department of Internal Medicine, Nyala Sudan Turkish Training Hospital, Nyala, Darfur, Sudan

2Department of Obstetrics and Gynecology, Nyala Sudan Turkish Training Hospital, Nyala, Darfur, Sudan ${ }^{3}$ Department of Internal Medicine, Akdeniz University Hospital, Antalya, Turkey

Fever generally occurs because of infections. It can also be seen due to malignancies, in particular, lymphomas. But it mostly occurs due to infections. The most common infections in the modern world are viral infections of the upper and lower respiratory tracts and gastrointestinal infections. In addition to this, bacterial infections of the urinary and upper respiratory tracts are among the most common fever etiologies in the modern world. Most of the time, viral infections heal without any treatment. All other bacterial infections are mostly treatable and are mostly not life-threatening in patients without any chronic diseases such as cancer, diabetes mellitus, chronic kidney disease, and acquired immune deficiencies.

Malaria is one of the major causes of fever in Sub-Saharan Africa. Plasmodium species are the causative agents of malaria. Plasmodium gametocytes are transmitted to human blood by mosquitoes. Malaria is mostly treatable. Plasmodium falciparum, which is the dominant-type parasite in Darfur, can cause cerebral malaria. Hence, it should be treated without any delay. It may result in rapid progression. Microscopes for diagnosing malaria are not available throughout Africa.. There are rapid diagnostic tests in such places. However, clinicians must diagnose malaria with a microscope, if available. Besides, clinicians must administer treatment to patients clinically suspected of malaria in the areas where only rapid diagnostic tests can be performed or where no tests are available.

Hepatomegaly and/or splenomegaly accompany fever sometimes in Sub-Saharan tropical Africa. Leishmaniasis, brucellosis, and schistosomiasis should also be kept in mind in the differential diagnosis in such situations. These agents can also result in other findings such as cytopenia. Schistosoma mansoni can induce chronic liver disease, and Schistosoma haematobium can induce bladder cancer.

There are also some other endemic viral diseases such as yellow fever, dengue fever, and Ebola virus disease in tropical Africa. The causative agent of yellow fever is also a virus, and the virus is transmitted to humans by mosquitoes. Clinical findings of yellow fever can include liver problems, kidney problems, fever, and abdominal pain. Dengue fever is also transmitted by mosquitoes. Dengue fever can present with fever, headache, muscle and joint pain, and bleeding. Ebola virus disease is transmitted by physical contact with contaminatedobjects or patients. It can present with liver and kidney function problems, bleeding, headache, and muscle and joint pain. Among these endemic viral diseases, there is a commercial live vaccine available for yellow fever disease.

The causative agents of fever also differ among the areas in Africa. Even within same states, Plasmodium falciparum may be more common in one part of the state, while Plasmodium malariae may be more common in other parts. Not all causative agents of fever are distributed throughout Africa. For instance, Ebola virus disease is more common in Central Africa.

In conclusion, Sub-Saharan Tropical Africa is a poor region. Preventive actions such as vaccination and using mosquito

Address for Correspondence / Yazışma Adresi: Dr. Özer Birge. E.mail: ozbirge@gmail.com DOI: 10.5152/tpd.2015.4427

(C) Copyright 2015 Turkish Society for Parasitology - Available online at www.tparazitolderg.org

CTelif hakkı 2015 Türkiye Parazitoloji Derneği - Makale metnine www.tparazitolderg.org web sayfasından ulaşılabilir. 
nets may be more cost-effective in Sub-Saharan Tropical Africa. The use of rapid diagnostic tests or microscopes could not be found in this region. The treatment of suspected common endemic diseases should be started in case there is no diagnostic tool.

Informed Consent: This article does not need informed consent, this is a letter to the editor.

Peer-review: Externally peer-reviewed.

Author contributions: Consept - A.M.; Design - A.M., Ö.B., F.A.M.; Supervision - A.M., Ö.B., F.A.M.; Materials - A.M., Ö.B., F.A.M.; Data Collection and/or Processing - A.M., Ö.B., F.A.M.; Analysis and/or Interpretation - A.M., Ö.B., F.A.M.; Literature Review - A.M., Ö.B., F.A.M.; Writer - A.M., Ö.B., F.A.M.; Critical Review - A.M., Ö.B., F.A.M.

Conflict of Interest: No conflict of interest was declared by the authors.
Financial Disclosure: The authors declared that this study has received no financial support.

Hasta Onamı: Bu çalışma editöre mektup olduğu için hasta onamı ihtiyacı yoktur.

Hakem Değerlendirmesi: Dış Bağımsız.

Yazar Katkıları: Fikir - A.M.; Tasarım - A.M., Ö.B., F.A.M.; Denetleme A.M., Ö.B., F.A.M.; Kaynaklar - A.M., Ö.B., F.A.M.; Malzemeler - A.M., Ö.B., F.A.M.; Veri Toplanması ve/veya işlemesi - A.M., Ö.B., F.A.M.; Analiz ve/veya Yorum - A.M., Ö.B., F.A.M.; Literatür taraması - A.M., Ö.B., F.A.M.; Yazıyı Yazan - A.M., Ö.B., F.A.M.; Eleştirel İnceleme - A.M., Ö.B., F.A.M.

Çıkar Çatışması: Yazarlar çıkar çatışması bildirmemişlerdir.

Finansal Destek: Yazarlar bu çalışma için finansal destek almadıklarını beyan etmişlerdir. 